\title{
Use of Cellulase enzyme obtained from Monilia (Moniliophthora roreri) for treatment of solid waste of Cob, Rice husks and Cocoa shell
}

\author{
Nataly Solís ${ }^{1 *}$, Carlos Chiriboga ${ }^{1}$, Rodrigo Ávalos ${ }^{1}$, Darwin Rueda ${ }^{1}$, Cristina Albán ${ }^{1}$, Bangeppagari Manjunatha ${ }^{1}$, \\ Bryan Rueda $^{2}$, Mariadoss Selvanayagam ${ }^{3,4}$ \\ ${ }^{1}$ Department of Life Sciences, Universidad de las Fuerzas Armadas-ESPE, Sangolquí- POBOX: 171-5-231B, Quito, Ecuador, South América. ${ }^{2}$ Department \\ of Biotecnology, Universidad de las Américas UDLA, Quito, Ecuador. ${ }^{3}$ Department of Environmental Engineering, Universidad Estatal Amazonica, Puyo, \\ Ecuador. ${ }^{4}$ Loyola - ICAM College of Engineering and Technology (LICET), Loyola campus, Chennai, India.
}

\begin{tabular}{|c|c|}
\hline ARTICLE INFO & ABSTRACT \\
\hline Article history: & \multirow{9}{*}{$\begin{array}{l}\text { Ecuador generates lots of lingo cellulosic organic waste from cocoa, rice and corn agribusiness, and these } \\
\text { products are rich in cellulose and can be used in fermentation processes by enzyme producing yeasts. In this } \\
\text { study, the phytopathogenic fungus Moniliophthora roreri was isolated, characterized and the kinetics of } \\
\text { production of cellulose was studied using rice husks, cocoa shell and cob as a growth inducer substance for a } \\
\text { period of } 20 \text { days. The carboxymethylcellulose }(\mathrm{CMC}) \text { was used as specific substrate to evaluate the kinetic } \\
\text { parameters of the enzyme at different concentration of } 0.5 \%, 1 \% \text { and } 1.5 \% \text {; to evaluate the Vmax, Km, specific } \\
\text { activity, Kcat we worked with the Michaelis-Menten and Line weaver-Burk linearization and the crude enzyme } \\
\text { was purified with ammonium sulfate. The enzyme production was increased on } 10^{\text {th }}, 15^{\text {th }} \text { and } 20^{\text {th }} \text { day in rice } \\
\text { husk, cocoa shell and cob, respectively. There was also an increased enzyme activity and the kinetic parameters } \\
\text { obtained from rice husk. The purification is a step to increase the specific activity of the enzyme in each of the } \\
\text { extracts is under study. }\end{array}$} \\
\hline 015 & \\
\hline Revis & \\
\hline & \\
\hline 2016 & \\
\hline & \\
\hline Moniliophthora roreri, & \\
\hline Cellulose, Enzyme activity, & \\
\hline $\begin{array}{l}\text { Enzyme purification, Kinetic } \\
\text { parameters. }\end{array}$ & \\
\hline
\end{tabular}

\section{INTRODUCTION}

Moniliophthora roreri is a parasitic fungus of the Neotropical plants, that attacks the fruit of the cocoa and causes Monilias is or watery rot, is one of the most representative diseases in cocoa farming (Suarez Contreras et al., 2014). External features of the disease are necrosis, deformation and rotting of ears, which are characterized by a brown color that eventually covers the cocoa shell with white plush (Sánchez et al., 2012). Cellulose is the major component of the cell wall in most plants. It is a polysaccharide composed of glucose units which are linked by $\beta$ 1-4 glycosidic bond, at least 500 residues of $\beta$-D-glucose covalently bonded (Baena et al., 2012). In the cellulose structure, there are amorphous regions with a heterogeneous composition characterized by a variety of links which are crucial for the biodegradation of cellulose. Moreover cellulose fibers contain sprains and spaces, in which large micro pores and capillaries were formed and allow the penetration of relatively large molecules, including cellulolytic enzymes (Gutierrez Ivonne Moreno et al., 2014). Enzymatic hydrolysis of cellulose involve the sequential action of a group of enzymes

\footnotetext{
* Corresponding Author

Email: natty_ss88@hotmail.com
}

known as cellulose, which belong to the super family of glycosylhydrolases, they catalyze the hydrolysis of the glycosidic bond between two or more carbohydrates (Gutierrez Ivonne Moreno et al., 2014). The enzyme activity was defined as the amount of an enzyme that, at optimum conditions of temperature, $\mathrm{pH}$ and ionic strength are able to transform into their respective products a micromole of substrate in one minute, and is known as IU unit international, and specific enzymatic activity refers to $\mathrm{mg}$ protein (Madrid and Pirámide, 2001). In general, purification by salt precipitation is the most common method for enzymes purification. This method depends on the hydrophobic nature of the protein surface. Predominantly hydrophobic groups inside, but some are located in different regions of the surface; water contacts with the surface, making these regions are exposed; when salt is added, water solves the salt ions, and as the salt concentration increases, the water is removed from around the protein, eventually exposing hydrophobic regions. Such regions in the proteins can interact with each other or with other molecules, resulting in the agglomeration. Thus, most abundant proteins with hydrophobic regions will form aggregates and precipitate more rapidly than those with few regions resulting fractionation. It has been shown that the best salt for protein precipitation is ammonium sulphate (Rojas and Victor, 2009). 
The objectives of this study was to evaluate the kinetics of cellulase enzyme obtained from Monilia (Moniliophthora roreri) grown on solid waste cob, rice husk and cocoa shell, and to determine the kinetics of enzyme production, and evaluation of kinetic parameters of Monilia on substrates under study with special reference to Cellulase-carboxymethylcellulose and carboxymethylcellulose in a purification step.

\section{MATRIALS AND METHODS}

Moniliophthora roreri was used for cellulases induction, grown on waste rice husks, cocoa shell and cob. Monilia was isolated and purified on PDA culture medium with antibiotic at $27^{\circ} \mathrm{C}$. A morphological and molecular characterization was carried out with the ITS region amplification technique using universal primers ITS1 and ITS4. The pathogenicity tests were also performed. To get cellulase enzymes that are responsible for the degradation of cellulose it preceded to plant the purified fungus in the three substrates studied. Once obtained the fungus-substrate complex, the extraction and evaluation of the cellulase activity was carried out using as a specific substrate for cellulose (carboxymethylcellulose) (CMC). Enzyme extracts were obtained on $5,7,10,13,15,18$ and $20^{\text {th }}$ day of fermentation, during this period physical observation was also made for any visible changes in the substrates and mycelia.

To determine the enzymatic activity of the cellulase, liquicolor Glucose kit (HUMAN) was used, which measures the concentration of glucose formation (reducing sugar) in the reaction, using $0.5 \%$ carboxymethylcellulose, $1 \%, 1.5 \% \mathrm{w} / \mathrm{v}$ in buffer sodium acetate-acetic acid $60 \mathrm{mM} \mathrm{pH}=6.5$ with $0.5 \mathrm{~mL}$ of each enzyme extract obtained on study days. A solution of ammonium sulfate at a concentration of $45 \%$ and $55 \%$, was used respectively for purification of the homogenized extract. Total protein quantification was performed with the biuret reagent, using the extract obtained in the processes of fermentation.

For specific cellulase activity the result of the total activity per mg protein of total protein obtained was divided. Later the model Michaelis-Mind and linearization charts LineweaverBurk to determine the Michaelis-Mind $(\mathrm{km})$ and maximum velocity (Vmax) was performed, finally the catalytic constant (kcat) and grades are calculated for purity.

\section{RESULTS AND DISCUSSION}

Moniliophthora roreri is a fungus whose spores exclusively infect cocoa pods (Phillips et al., 2014). After isolating and purifying the fungus obtained from cocoa pods with signs and symptom of disease in PDA medium, we obtained a $90 \%$ growth after 7 days of inoculation, evidencing a white, cotton-like texture, which according to (Arbelaez and Lina 2010), is a characteristic trait of Monilia. The color of the mycelium can vary from creamy white to brown, depending on the species. The structures of the hyphae found herein showed the same characteristics of those in study (Villavicencio and Miriam, 2010), showing septa and globular and ellipsoid spores. The morphological and molecular characterization classifies the fungus in the genus Moniliophthora roreri.

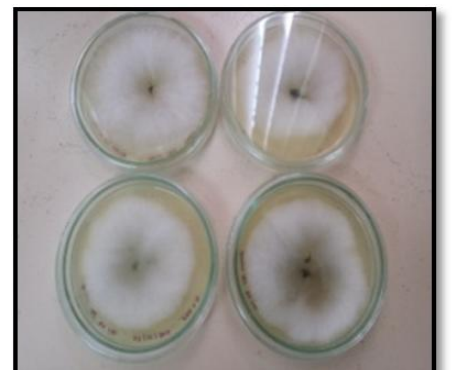

(A)

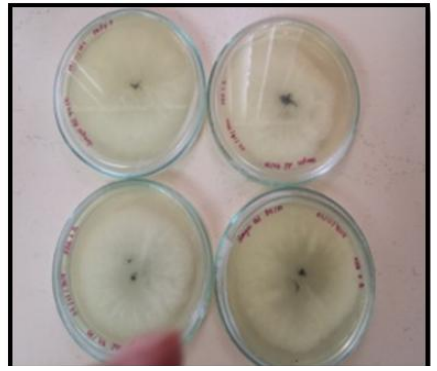

(B)
Fig. 1: Characterization of Moniliophthora roreri colonies. A) Front view and B) Back view

Once the fungus-substrate complex was obtained, the extracted cellulase activity was assessed by using carboxymethylcellulose. The determination of enzymatic activity is a means of measuring the volume of enzymes formed during solid fermentation in a determined substrate (Paredes, 2010). This study used carboxymethylcellulose as the specific substrate and evidenced that the enzymatic activity is low at a $0.5 \%$ concentration, but increases at 1 and $1.5 \%$ concentrations. This allowed determining the kinetics of the enzyme's behavior (Figure 4 and 5, which were hyperbolic. The statistical analysis using InfoStat verified that 1 and $1.5 \% \mathrm{CMC}$ concentrations are not significantly different, which means that the maximum reaction speed of this substrate occurs between 1 and $1.5 \%$ concentration.

The best strain-substrate interaction, from which an enzyme extract can be obtained, with maximum activity, is rice husk, with an average net enzymatic activity of 24.92 UI in homogenized extract and $34.84 \mathrm{UI}$ in purified extract. It is worth noting that the results of the analysis carried out with InfoStat showed a significant difference for the three studied extracts, which indicates that enzymatic activity does depend on the extract used. Furthermore, cocoa husk, on day 20, considerably increased its enzymatic activity to 54.78 UI (Figure 2).

Rice bran had the highest kinetic parameters when compared it with cocoa shell and cob, got the following results, U: 321.54 662.25 UI and UI, Kcat: 10335.921287 .42 min-1 min-1, e: $232.16 \mathrm{IU} / \mathrm{mg}$ and $2388.48 \mathrm{IU} / \mathrm{mg}$, for the homogenized extracts and purified extracts, respectively, demonstrating that this extract caused a higher concentration of the cellulase enzyme. By having a larger number of parts (kcat) a greater number of moles of substrate converted per mole of enzyme in the time unit (Madrid and Pirámide, 2001).

The evaluation of disease symptoms is presented in Figure 3 and Table 1 which showed a daily advance in the infection of the cocoa shells by the spores of the fungus causing brown spots and white mycelium growth, with the appearance of oily stains. After approximately 20 days of growth the shells were completely deformed and dry, according to (Sánchez et al., 2012), these are the characteristic symptoms of Moniliasis, and the time course of the disease varies by age of the fruit. 


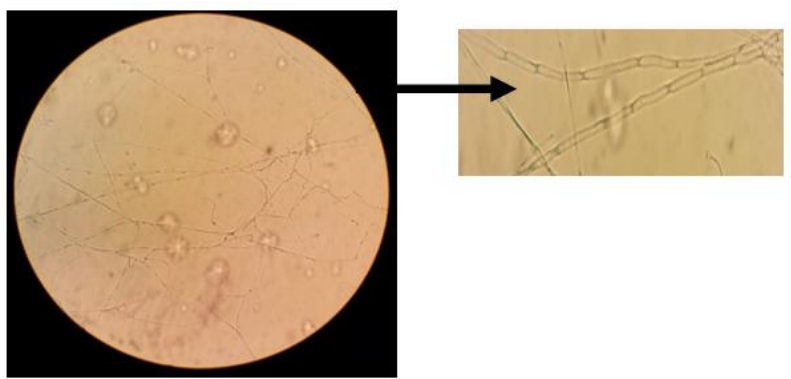

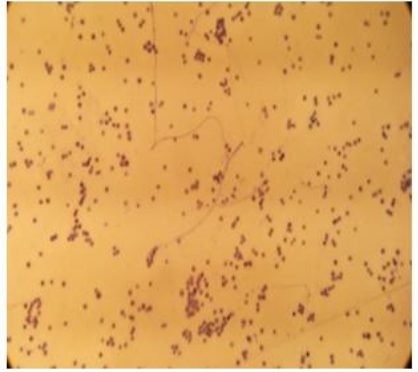

(A)

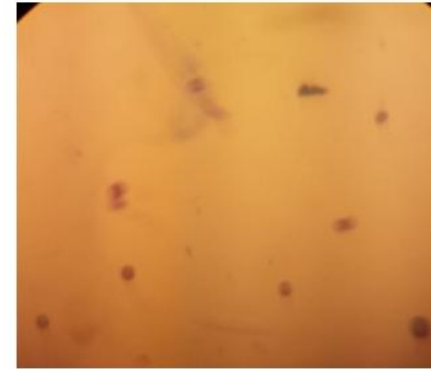

(B)

Fig. 2: Microscopic characterization of Moniliophthora roreri; A) septate hyphae and B) round and ovoid spores.

Table 1: Results of the test of symptoms of Monilia planted in the cocoa shells.

\begin{tabular}{cl}
\hline TIME (days) & OBSERVATIONS \\
\hline $\mathbf{1}$ & $\begin{array}{l}\text { Healthy cocoa, spotless and sterilized. } \\
\text { Appearance of a small coffee stain, stain- } \\
\text { defined edges. } \\
\text { Growth of mycelium white, on the macha. } \\
\text { Coffee stain color, approximately 90\% of } \\
\text { the cocoa shell. }\end{array}$ \\
$\mathbf{1 0}$ & $\begin{array}{l}\text { Full coverage of the mycelium on the } \\
\text { cocoa shell (mummified shell). } \\
\text { Total necrosis in Cocoa shell. }\end{array}$ \\
\hline
\end{tabular}

Once the purified strain was obtained, and inoculated on the substrates: rice husk, cocoa shell and cob for fermentation, which are according to (Garces, 1987), cellulose, it serves as a carbon source for fungal growth. With these substrates microorganism growth was induced. The rapid growth of Monilia in cacao shell was because of the availability of the essential nutrients necessary for their development. On the seventh day of fermentation in the rice husk showed better coupling of the fungus, while on the cob fungal growth was very slow, because it contains only about $8 \%$ of cellulose (Garces, 1987). Because of the fermentation caused by microorganisms, $\mathrm{CO}_{2}$ gas was produced in each treatment.

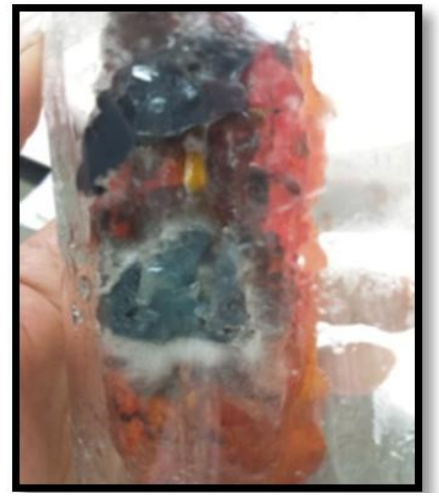

(A)

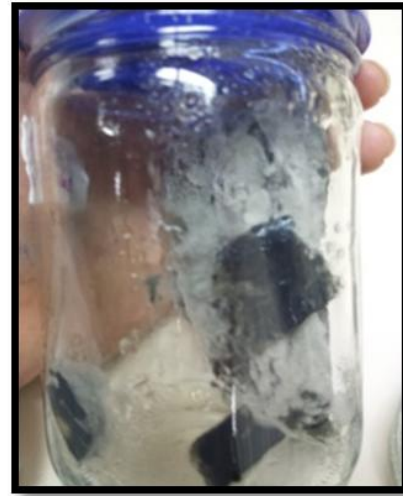

(B)
Fig. 3: Test symptomatology. A) Samples of healthy cocoa with the inoculum of Monilia and B) Cocoa shells fifteenth day of inoculation.

In order to have a better utilization of cellulose, it is necessary to make a pre-treatment of the substrates. All the three substrates were exposed to two stages of pretreatment, namely mechanical and hot water, in order to dissociate the complex cellulose, to dissociate the complex cellulose - lignin and decrease the presence of substances that hinder hydrolysis. According to Hendriks and Zeeman (2009), the mechanical pre-treatment allows the reduction of particle size and crystallinity in order to increase the available surface and reduced the degree of polymerization, the yield of the hydrolysis depends on the type of biomass and type ground; and pretreatment with hot water aims primarily to solubilize the hemi cellulose to cellulose more accessible and prevent inhibitor formation.

In this study a specific substrate carboxymethylcellulose was used and it showed that at $0.5 \%$ of the concentration of substrate, enzyme activity is low, but in $1 \%$ and $1.5 \%$ the speed increases with the kinetic behavior of the enzyme (Figure 4 and 5) thus showing a hyperbolic behavior. When analyzing the statistical program InfoStat, it is found that concentrations of $1 \% \mathrm{CMC}$ and $1.5 \%$ are not significantly different, which means that for maximum reaction rate, the substrate concentration should be in the range of 1 to $1.5 \%$.

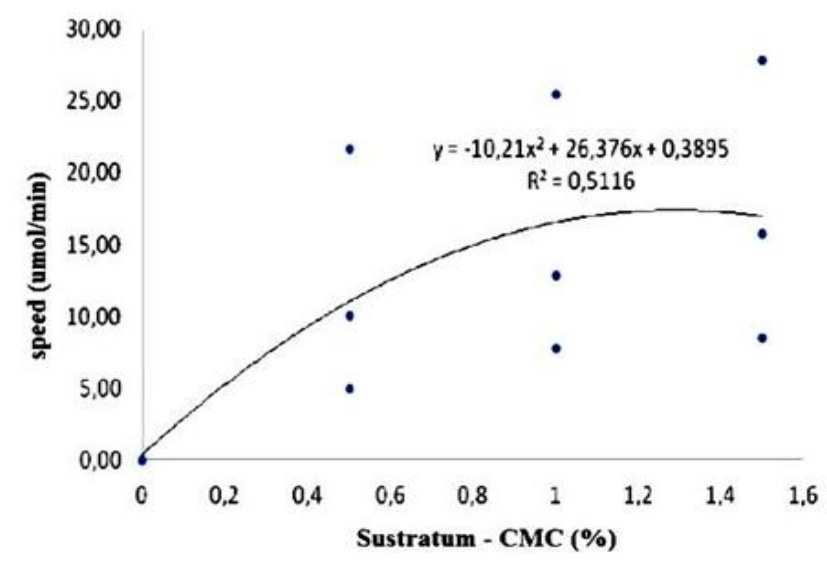

Fig. 4: Michaelis-Menten representation model of enzyme cellulase (homogenized extracts).

The best strain-substrate interaction of an enzyme extract with a maximum activity is in rice husks with an average net enzymatic activity of 24.92 IU 34.84 IU homogenized in extract and purified extract. It is emphasized that the results of the analysis with the statistical program InfoStat show a significant difference for the three extracts under study, which means that the highest enzyme activity depends on the extract. It is noteworthy to mention that the increased enzyme activity was noticed in hat cocoa shell on 20 day IU 54.78 (Figure 6). 


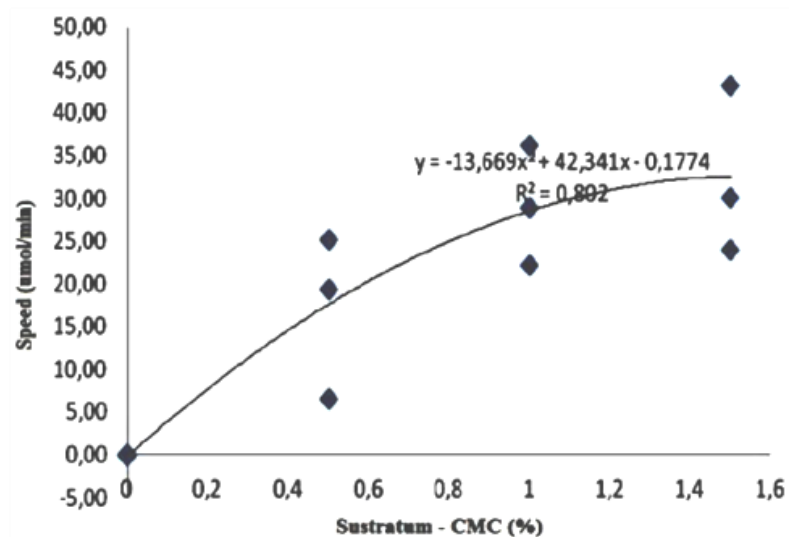

Fig. 5: Representation of the Michaelis-Menten model of enzyme cellulase (purified extracts).

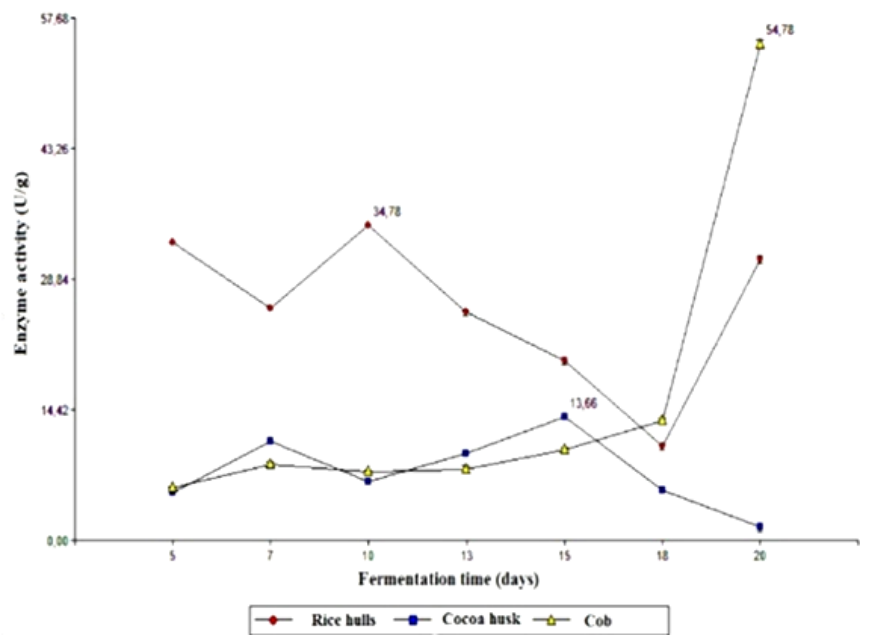

Fig. 6: Net enzymatic activity on substrates: rice hulls, cocoa husk and cob.

The Michaelis constant $(\mathrm{Km})$, represents the affinity of the enzyme for the substrate (Madrid and Pirámide, 2001), and is characteristic of the substrate; in this study the same specific substrate was used, the carboxymethylcellulose, thus the $\mathrm{Km}$ has approximately the same value in both homogenates extracts and purified extracts. The purity in the initial stage is 1 , but with purification process contaminating proteins were lost and were obtained 10.29 rice husks, 15.35 in the cocoa husk and 3.45 on the cob thus shows that the specific activity increases in each of the substrates studied (Table 4).

Rice bran had the highest kinetic parameters when compared with cocoa shell and cob, with the following results, U: 321.54662 .25 UI and UI, Kcat: $10335.921287 .42 \mathrm{~min}^{-1}$, e: 232.16 $\mathrm{IU} / \mathrm{mg}$ and $2388.48 \mathrm{IU} / \mathrm{mg}$, of the homogenized extract and purified extracts, respectively, demonstrating that this extract there was a greater concentration of cellulase enzyme. By having a larger number of parts (kcat) a greater number of moles of substrate converted per mole of enzyme in the time unit (Madrid and Pirámide, 2001).
Table 2: Kinetic parameters of homogenized extracts.

\begin{tabular}{|c|c|c|c|c|c|c|}
\hline 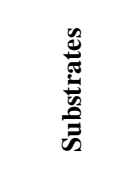 & 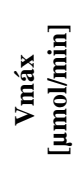 & $\frac{\sum}{\underline{\Xi}}$ & 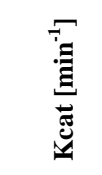 & 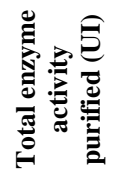 & 然 & $\frac{B 0}{g}$ \\
\hline Rice husk & 32.15 & 0.01 & 10335.69 & 321.54 & 1.385 & 232.16 \\
\hline Shell cocoa & 14.81 & 0.04 & 4762.07 & 148.15 & 4.525 & 32.74 \\
\hline Cob & 20.79 & 0.02 & 6682.75 & 207.90 & 1.140 & 182.37 \\
\hline
\end{tabular}

Table 3: Kinetic parameters of purified extracts

\begin{tabular}{|c|c|c|c|c|c|c|}
\hline 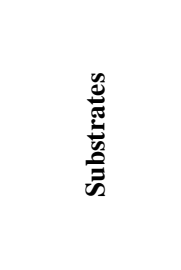 & 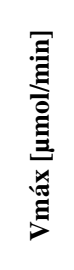 & $\Xi \Sigma$ & 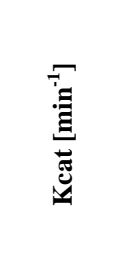 & 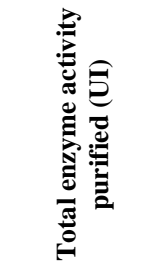 & 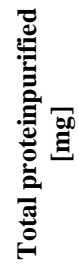 & 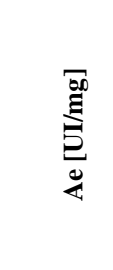 \\
\hline Rice husks & 66.23 & 0.03 & 21287.42 & 662.25 & 0.277 & 2388.48 \\
\hline Shell cocoa & 45.45 & 0.03 & 14610.91 & 454.55 & 0.905 & 502.53 \\
\hline Cob & 14.31 & 0.03 & 4598.57 & 143.06 & 0.228 & 628.33 \\
\hline \multicolumn{2}{|l|}{ Substrates } & \multicolumn{2}{|c|}{$\begin{array}{c}\text { Ae } \\
\text { [IU/mg] } \\
\text { (unpurified) }\end{array}$} & $\begin{array}{c}\text { Ae }[\mathrm{UI} / \mathrm{mg}] \\
\text { (purified) }\end{array}$ & \multicolumn{2}{|r|}{ Purities } \\
\hline \multirow{3}{*}{$\begin{array}{l}\text { Rice husks } \\
\text { Shell cocoa } \\
\text { Cob }\end{array}$} & \multicolumn{3}{|c|}{232.16} & 2388.48 & \multicolumn{2}{|r|}{10.29} \\
\hline & \multicolumn{3}{|c|}{32.74} & 502.53 & \multicolumn{2}{|r|}{15.35} \\
\hline & \multicolumn{3}{|c|}{182.37} & 628.33 & \multicolumn{2}{|r|}{3.45} \\
\hline
\end{tabular}

Thus the results show that Monilia produces more cellulases, compared with the results of Rueda and Alexandra (2015) with Bacillus subtilis as obtained kinetic parameters were at the speed of UI 129.77, 263.75 Specific activity IU/mg and Kcat: 1165.79 min-1. In addition, according to Rueda and Alexandra (2015), Bacillus subtilis produces higher concentrations of cellulase on the cob, and the present study showed that Moniliophthora roreri produce more of these enzymes when grown in rice husk.

\section{CONCLUSION}

It was determined that at a $0.5 \%$ of the concentration of carboxymethylcellulose (Cellulase specific substrate) enzyme activity is low, with concentrations of $1 \%$ and $1.5 \%$ the speed increases, with this kinetic behavior of the enzyme was determined, the same resembling a hyperbolic behavior. Cellulase enzymes were obtained from the fermentation process by the fungus Monilia on substrates: rice husk, cocoa shell and cob, being the best rice husks that produced an enzyme extract with the maximum enzymatic activity $321.54 \quad 662.25$ UI and UI, homogenates and purified, respectively. Net enzyme activity in the days of fermentation shows that the highest corresponds to the tenth day of fermentation in the rice bran with $34.78 \mathrm{IU}$, fifteenth day of fermentation in cocoa shell with 13.66 UI and twentieth day of fermentation on the cob with 54.78 UI. By performing the purification with ammonium salt greatly increased the specific activity of each substrate, therefore the studies of enzyme activity is important necessarily to fulfill at least one purification step. 


\section{CONFLICT OF INTERESTS}

The authors declare that there is no conflict of interest regarding the publication of this paper.

\section{REFERENCES}

Arbeláez Arias, Lina María. Analysis of aintra-species diversity of Moniliophthora roreri (Cif.) Evans et al. using morphological and genetic markers. M.Sc. thesis Bacteriology-National University of Colombia, Medellin Colombia. 2010; pp 67. Available online at: http://www.bdigital.unal.edu.co/1938/1/43276997.20101.pdf.

Baena Luz, García Natalia. 2012. Preparation and characterization of dietary fiber from the husk of the roasted seeds of Theobroma cacao chololatera a Colombian industry. Pereira: Thesis, Technological University of Pereira. pp. 78. Available online at: www.ruta.org/CDOC-Deployment/.../Elaboración_de_fibra.pdf.

Garcés N. 1987. High lands cultures, Ecuador: Central University, Agricultural Sciences. Quito. pp. 5-9. Available online at: http://dspace.ueb.edu.ec/bitstream/123456789/1009/1/046.pdf.

Gutierrez Ivonne Moreno, Nubia, Montoya and Dolly. Regulatory mechanisms of enzymatic hydrolysis of cellulose in filamentous fungi: classical and new models instances. Revista Iberoamericana de Mycology. 2014; p. 12.

Hendriks, A. and G. Zeeman. Pretreatments to Enhance the digestibility of lignocellulosic biomass. Bioresoruce Technology, 2009; $10-18$.

Luz Marina Baena, Natalia Andrea Garcia Cardona. Preparation and characterization of dietary fiber from the husk of the roasted seeds of Theobroma cacao chololatera a Colombian industry. Pereira: Ph.D. thesis, Technological University of Pereira. 2012; pp 78. Available online at: http://www.ruta.org/ CDOC-Deployment/documentos/Elaboraci\%C3\%B3 n_de_fibra.pdf.

Madrid, España, Ediciones Pirámide, Núñez and Ignacio. Enzymology, 2001.

Paredes, D, M. Alvarez, M. Silva. Getting enzymes cellulases by Solid Fermentation Fungi for use in the process of obtaining Bioalcohol Waste of banana cultivation. Journal of Technology ESPOL, 2010; 81-88.

Phillips, Wilberth, Cerda and Rolando. Catalog cacao diseases in Central America. 2014. Available at: http://orton.catie.ac.cr/repdoc/ A7372E/ A7372E.PDF.
Rojas Victor R. Evaluation of extraction methods and purification of pectinolytic enzymes obtained by fermentation of Aspergillus niger semisolid state. Thesis, Medellin, Colombia: Research Group and Environmental Biotechnology, 2009. pp. 58. Available online at: $\quad$ https://repository.eafit.edu.co/bitstream/handle/10784/373/ VictorRene_RojasMu\%F1oz_2009.pdf.

Rueda Alexandra E. 2015. Evaluation of enzymatic activity of the cellulase obtained and purified from Bacillus subtilis grown on substrates rice hulls, oat hulls and cob. Universidad de las Fuerzas Amadas ESPE, Thesis, Ecuador, 2015. pp. 66. Available online at: http://repositorio.espe.edu.ec/handle/21000/10377.

Fernando David Sánchez Mora and Felipe Rafael Garcés Fiallos. Moniliophthora roreri (Cif y Par) Evans et al. in the crop of cocoa. Scientia Agropecuaria, 2012; 3: 249 - 258. Available online at: https://www.researchgate.net/publication/237073698.

Suárez Contreras, Liliana Yanet, \& Rangel Riaño, Alba Luz.. Isolation of microorganisms for biological control of Moniliophthora roreri. Acta Agronómica, 2013; 62(4), 370-378.

Villavicencio Vásquez, Mirian Elizabeth. Morphological, physiological and pathogenic Moniliophthora roreri isolates of five provinces of the Ecuadorian coast. Polytechnic School of the Coast, Guayaquil, Ecuador, 2010. Available online at: http://prisma.dspace. espol.edu.ec/rl-eng/archives/11678

\section{How to cite this article:}

Solís N, Chiriboga C, Ávalos R, Rueda D, Albán C, Manjunatha B, Bryan Rueda, Mariadoss Selvanayagam. B. Use of Cellulase enzyme obtained from Monilia (Moniliophthora roreri) for treatment of solid waste of Cob, Rice husks and Cocoa shell. J App Pharm Sci, 2016; 6 (03): 066-070. 